\title{
Endometrial Cancer in 40 Years Old or Younger: A Single Center Experience
}

\section{Yaş ve Daha Genç Hastalarda Endometrium Kanserleri \\ CGülşah Selvi Demirtaş', @Mehmet Gökçü'}

'Tepecik Education and Research Hospital, Department of Gynecologic Oncology, İzmir, Turkey

\begin{abstract}
Purpose: The purpose of this study was to identify prognostic factors associated with successful survival outcome of endometrial cancer (EC) in women aged $\leq 40$ years.

Material and Method: This was a retrospective cohort study. The medical records of all women aged $\leq 40$ years with EC diagnosed on endometrial curettage between 1995 and 2020 were reviewed. Patients who underwent hysterectomy with histopathological evaluation in the same hospital, or who were evaluated by the members of the tumor board and followed up in our hospital, were included in the study.
\end{abstract}

Results: Median follow-up was 79 months (range 9-192). 42 of 44 patients underwent surgical intervention. $33.4 \%(n: 14)$ underwent total abdominal hysterectomy (TAH), bilateral salpingo-oophorectomy (BSO), and pelvic paraaortic lymph node dissection (PPLND). 61.9\% (n:26) underwent TAH BSO, and PLND. In one patient $(2.4 \%)$ only $\mathrm{TAH}$ and in the other patient $(2.4 \%)$ $\mathrm{TAH}$ BSO was performed. Medical treatment was administered to 2 patients who desired to preserve their fertility and had grade 1 endometrioid adenocarcinoma without any evidence of myometrial invasion and extra-uterine disease. 26 (59.1\%) patients had grade 1, 15(34.1\%) had grade 2, and 3(6.8\%) had grade 3 adenocarcinoma. CA 125 level $\geq 35 \mathrm{IU} / \mathrm{ml}$ was statistically associated with lymph node metastasis $(p=0.004),>50 \%$ myometrial invasion $(p=0.044)$, and advanced-stage disease $(p=0.048)$.

Conclusion: CA 125 level $\geq 35 \mathrm{lU} / \mathrm{ml}$ was statistically associated with lymph node metastasis, deep myometrial invasion, and advanced-stage disease in EC patients $\leq 40$ years of age.

Keywords: CA 125, Endometrial cancer, Treatment, Young patients
Öz

Amaç: Bu çalışmanın amacı $\leq 40$ yaş kadınlarda endometriyal kanserin (AK) başarılı sonucu ile ilişkili prognostik faktörleri belirlemekti.

Gereç ve Yöntem: Bu çalışma retrospektif bir kohort çalışmasıdır. 1995 ve 2020 yılları arasında endometriyal küretajda EC tanısı almış $\leq 40$ yaşındaki tüm kadınların tıbbi kayıtları gözden geçirildi. Histerektomi yapılan ve son histopatolojik değerlendirmesi hastanemizde yapılan veya tümör kurulu üyeleri tarafından değerlendirilerek hastanemizde takip edilen hastalar çalışmaya dahil edildi.

Bulgular: Medyan takip 79 aydı (9-192 ay). 44 hastadan 42'sine cerrahi müdahale yapıldı. \%33,4'üne (n: 14 ) total abdominal histerektomi (TAH), bilateral salpingo-ooferektomi (BSO) ve pelvik paraaortik lenf nodu diseksiyonu (PPLND) yapıldı. \%61,9'una (n: 26) TAH BSO ve PLND uygulandı. Bir hastada (\%2.4) sadece TAH, diğerinde (\%2.4) TAH BSO yapıldı. Miyometriyal invazyon kanıtı olmayan doğurganlığını korumak isteyen ve evre 1 endometrioid adenokarsinomu olan 2 hastaya, medikal tedavi uygulandı ve bu hastaların kapsamlı değerlendirmesinde rahim dışında hastalık kanıtı gözlenmedi. 26 (\%59.1) hastada 1. derece, 15 (\%34.1) hastada 2. derece ve 3. (\%6.8) hastada 3. derece adenokarsinom vardı. CA 125 $\geq 35 \mathrm{IU} / \mathrm{ml}$ istatistiksel olarak lenf nodu metastazı ( $p=0,004)$, >\%50 miyometriyal invazyon $(p=0,044)$ ve ileri evre hastalık $(p=0,048)$ ile ilişkili bulundu.

Sonuç: CA $125 \geq 35$ IU / ml, 40 yaşındaki EC hastalarında istatistiksel olarak lenf nodu metastazı, derin miyometriyal invazyon ve ileri evre hastalık ile ilişkiliydi.

Anahtar Kelimeler: CA 125, endometrium kanseri, tedavi, genç hastalar

Corresponding (illetişim): Gulsah Selvi Demirtas, Tepecik Research and Education Hospital, Department of Gynecologic Oncology, İzmir, Turkey E-mail (E-posta): drg.selvi@gmail.com 


\section{INTRODUCTION}

Endometrial cancer (EC) is the most common malignancy of the female genital tract in developed countries. ${ }^{[1]}$ Genetic syndromes (Lynch Syndrome, Cowden Syndrome), nulliparity, insulin resistance, diabetes mellitus, hypertension, and obesity play role in EC development. EC commonly occurs in postmenopausal women and at diagnosis, the median age is 61 years. ${ }^{[2]}$ In literature, the incidence of endometrial adenocarcinoma in women $\leq 40$ years of age was reported to be approximately $5 \% .^{[3,4]}$

Patients $\leq 40$ years of age generally have a history of abnormal uterine bleeding, infertility, obesity, polycystic ovary syndrome (PCOS), and high estrogen levels..$^{[5]}$ These patients who desire to preserve fertility should be carefully evaluated with appropriate consultation. For these patients, evaluating the involvement of the myometrium, tumor grade, and type is crucial. In grade 1 endometrioid carcinomas the exclusion of any myometrial involvement can be regarded as a criterion for conservative treatment. ${ }^{[6]}$ In young patients, EC tends to behave favorably when compared to older women. In this study, we aimed to evaluate the clinicopathologic features and clinical value of CA 125 level in patients $\leq 40$ years of age with EC. We also reviewed the treatment approaches, overall (OS) and disease free survival (DFS), and the course of the disease within the surgical and medical treated groups.

\section{MATERIAL AND METHOD}

This was a retrospective study, conducted at Tepecik Training and Research Hospital, İzmir between 1995 and 2020. Medical records of all women aged $\leq 40$ years diagnosed with endometrial cancer as a result of endometrial curettage were reviewed. Approvals for the study were obtained from the hospital management and education coordination board. Patients 40 years of age or younger, who underwent hysterectomy and whose final histopathological evaluation was made in our hospital, or who were evaluated by the members of the tumor board and followed up in our hospital, were included in the study. Files of 3878 patients diagnosed with endometrial cancer were examined retrospectively by the same investigator. 3824 patients who were $>40$ years of age and 10 patients who were $<40$ years of ager were excluded from the study due to inadequate data. Finally, 44 patients were included to the study.

The study subjects' past medical history, gravidity, parity, surgical procedure history, preoperative and postoperative histopathologic results, tumor grade, tumor size, preoperative CA 125 levels, depth of myometrial invasion (MI), pelvic (P), paraaortic (PA) lymph node (LN) metastasis, lymphovascular space invasion (LVSI), stage of the disease, and applied adjuvant therapies were reviewed. Two of 44 patients did not undergo surgery and received medical treatment. $\mathrm{Ml}$ was classified into two groups 1 ) $\leq 50 \%$ invasion 2 ) $>50 \%$ invasion of.
Patients were staged according to the FIGO 2009 guidelines. There were 3 patients before this 2009 guideline. One patient had $\leq 50 \%$ invasion (staged as IA according to FIGO 2009), 1 had pelvic lymph node metastasis (staged as IIIC1), and 1 had paraaortic lymph node metastasis (staged as III3C2). The use of adjuvant radiotherapy (RT), chemotherapy (CT), or combination therapy, was based on the stage, lymph node metastasis, medical comorbidities, and patient's performance status. Patients were followed every 3 months for the first 2 years, every 6 months for the next 3 years, and then annually.

Statistical analysis was performed with SPSS version 22 (SPSS for Mac Inc., Chicago, IL, USA). P-value $<0.05$ was considered statistically significant.

\section{RESULTS}

Forty-four endometrial cancer patients 40 years old or younger were evaluated (Table 1). The mean age was $36.2 \pm 3.2$ years. The mean tumor size was $3.1 \pm 2.5 \mathrm{~cm}$. Due to the strong desire for fertility preservation, two patients evaluated in detail by the members of the tumor board, consisting of a radiologist, gynecological oncologist, radiation oncologist, medical oncologist, and pathologist. These two patients had grade 1 endometrioid adenocarcinoma, normal CA125 level, and normal body mass index (BMI). Pelvic magnetic resonance imaging (MRI) did not show any MI, extrauterine spread, or adnexal pathology. Median follow-up was 79 months (range 9-192). Twenty-six (61.9\%) of 42 patients underwent total abdominal hysterectomy (TAH) and bilateral salpingooophorectomy (BSO), peritoneal cytology, and pelvic and paraaortic lymph node dissection (PPLND). One patient underwent only TAH, one TAH BSO, and 14 patients TAH BSO, and PLND. In 28 (66.7\%) patients the histopathology revealed deep myometrial invasion (>50\%). Twenty-six (59.1\%) tumors were grade 1 and 3 were $(6.8 \%)$ grade 3 . The cancer in 34 patients (81.0\%) was at stage I, $2(4.8 \%)$ at stage II and $6(14.3 \%)$ at stage III. Of the stage III patients, 2 had adnexal micrometastasis, and 3 had lymph node metastasis without extra-capsular extension. CT and RT were administered to all patients with stage III disease.

LVSI was present in $33(78.6 \%)$ patients. Adjuvant therapy was administered to $13(30.9 \%)$ of the 42 patients who underwent hysterectomy. Six patients received only RT, 6 patients recieved both RT and CT, 1 patient received CT only. Recurrence occurred in 2 patients ( 34 and 36 years old, respectively) who underwent TAH BSO, peritoneal cytology, and PPLND. These patients had endometrioid grade 1 disease with $>50 \%$ myometrial invasion. One of the patients developed liver metastasis ( 85 months after surgery), while the other had a vaginal cuff recurrence 49 months after surgery). The patient with vaginal cuff recurrence received RT and the patient with liver metastasis underwent surgical intervention. 
Forty patients underwent lymph node dissection. Three patients (7.5\%) had metastasis to pelvic lymph nodes only, $2(5 \%)$ had pelvic and paraaortic and 1(2.5\%) metastasis to paraaortic lymph node only. Two of the 44 patients received only medical treatment. Both had grade 1 endometrioid adenocarcinoma. One received megestrol acetate and one received an intrauterine levonorgestrel device. After 3 months of treatment,

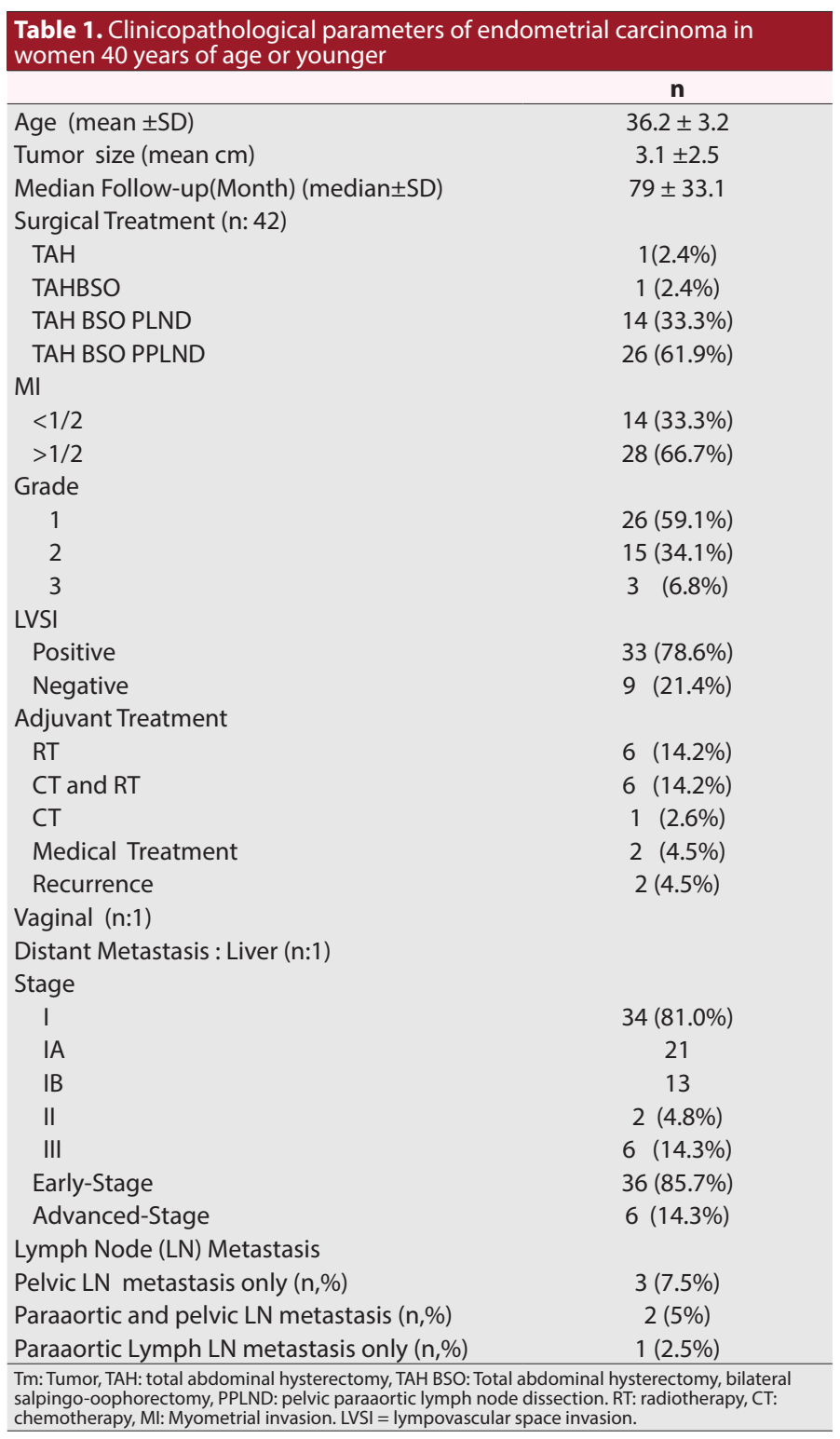

dilatation and curettage was performed. One of them had focal atypical endometrial hyperplasia within an endometrial polyp and regression within the rest of the endometrium. The other patient had complete regression. At 6 months intervals these patients were evaluated with endometrial biopsy. After 3 years one patient underwent surgical intervention. These patients had not achieved pregnancy after the 36th month of the medical treatment. In another patient, concomitant endometrioid, histologic grade 1 ovarian cancer was detected. This patient had a recurrence at the vaginal cuff.

CA 125 level $\geq 35 \mathrm{lU} / \mathrm{ml}$ was statistically significantly associated with lymph node metastasis $(p=0.004),>50 \%$ myometrial invasion, $(p=0.044)$ and advanced-stage disease $(p=0.048)$. (Table 2). There was also a statistically significant association of tumor grade with lymph node metastasis $(P<0.001$ (Table 3). In univariate cox regression analysis stage, tumor size, LVSI, CA 125 level, tumor grade, RT and recurrence had no impact both on OVS and DFS ( $n: 42)$ ( $p>0.05$ ) (Table 4).

CA 125 levels were not statistically significantly associated with DFS and OS ( Log rank $p=0.08, p=0.08$, respectively) (Figure 1A and Figure 1B). Surgically treated patient's mean OS was $182.1 \pm 6.8$ months. The 5 -year OS rate was $91.6 \%$ ( $\mathrm{n}$ : 42) (Figure 1C).

Table 2. Ca 125 levels and clinicopathological parameters of endometrial carcinoma in women 40 years of age or younger

\begin{tabular}{lccc} 
& CA 125 $<\mathbf{3 5}$ & CA125 $\geq \mathbf{3 5}$ & P \\
\hline Lymph node (n:38) & $0(0 \%)$ & $3(100 \%)$ & 0.004 \\
$\quad$ Positive & $31(88.6 \%)$ & $4(11.4 \%)$ & \\
$\quad$ Negative & & & 0.044 \\
Myometrial Invasion (n:42) & $14(40 \%)$ & $0(0 \%)$ & \\
$\quad \leq 50 \% \mathrm{MI}$ & $21(60 \%)$ & $7(100 \%)$ & \\
$\quad>50 \% \mathrm{MI}$ & & & 0.048 \\
Stage & $32(88.9 \%)$ & $4(11.1 \%)$ & \\
$\quad$ Early (Stagel, II) & $3(50 \%)$ & $3(50 \%)$ & \\
$\quad$ Advanced (Stage III, IV) & & & 0.15 \\
LVSI & $29(87.9 \%)$ & $4(12.1 \%)$ & \\
$\quad$ Positive & $6(66.7 \%)$ & $3(33.3 \%)$ & \\
$\quad$ Negative & & & \\
\hline LVSI = Lympovascular Space Invasion & &
\end{tabular}

Table 3. Association between tumor grade and lymph node metastasis

\begin{tabular}{|c|c|c|c|}
\hline \multirow{2}{*}{ Grade } & \multicolumn{2}{|c|}{ Lymph Node Metastasis } & \multirow{2}{*}{$\begin{array}{c}P \\
<0.001\end{array}$} \\
\hline & No & Yes & \\
\hline Grade 1 & $21(100 \%)$ & $0(0 \%)$ & \\
\hline Grade 2 & 13 (92.9\%) & $1(7.1 \%)$ & \\
\hline Grade 3 & $1(33.3 \%)$ & $2(66.7 \%)$ & \\
\hline
\end{tabular}

\begin{tabular}{|c|c|c|c|c|c|c|c|}
\hline $\begin{array}{l}\text { Univariate analysis } \\
\text { Overall Survival }\end{array}$ & $P$ value & OR & $95 \% \mathrm{Cl}$ & $\begin{array}{l}\text { Univariate analysis } \\
\text { Disease free Survival }\end{array}$ & $P$ value & OR & $95 \% \mathrm{Cl}$ \\
\hline Stage & 0.61 & 1.55 & $0.27-8.9$ & Stage & 0.63 & 1.53 & $0.26-8.81$ \\
\hline Tumor size & 0.45 & 1.18 & $0.76-1.85$ & Tumor size & 0.42 & 1.19 & $0.77-1.85$ \\
\hline LVSI & 0.42 & 3.10 & $0.19-49.7$ & LVSI & 0.40 & 3.23 & $0.20-51.7$ \\
\hline CA 125 & 0.15 & 8.15 & $0.44-148.3$ & CA 125 & 0.15 & 8.41 & $0.45-155.4$ \\
\hline Tumor grade & 0.59 & 0.05 & $0,00-2479.2$ & Tumor grade & 0.58 & 0.05 & $0.00-1836.3$ \\
\hline RT & 0.63 & 1.94 & $0.12-31.2$ & $\mathrm{RT}$ & 0.61 & 2.02 & $0.12-32.7$ \\
\hline
\end{tabular}




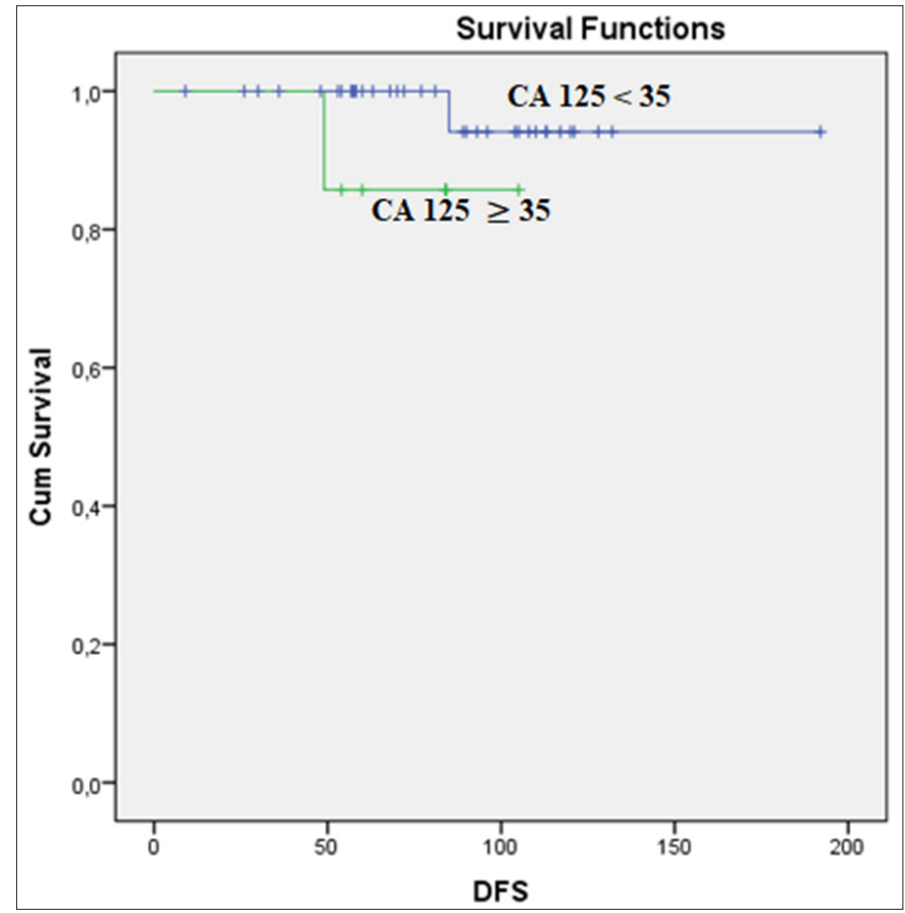

Figure 1A. Disease-free survival kaplan-meier curves of the patients according to the ca 125 level

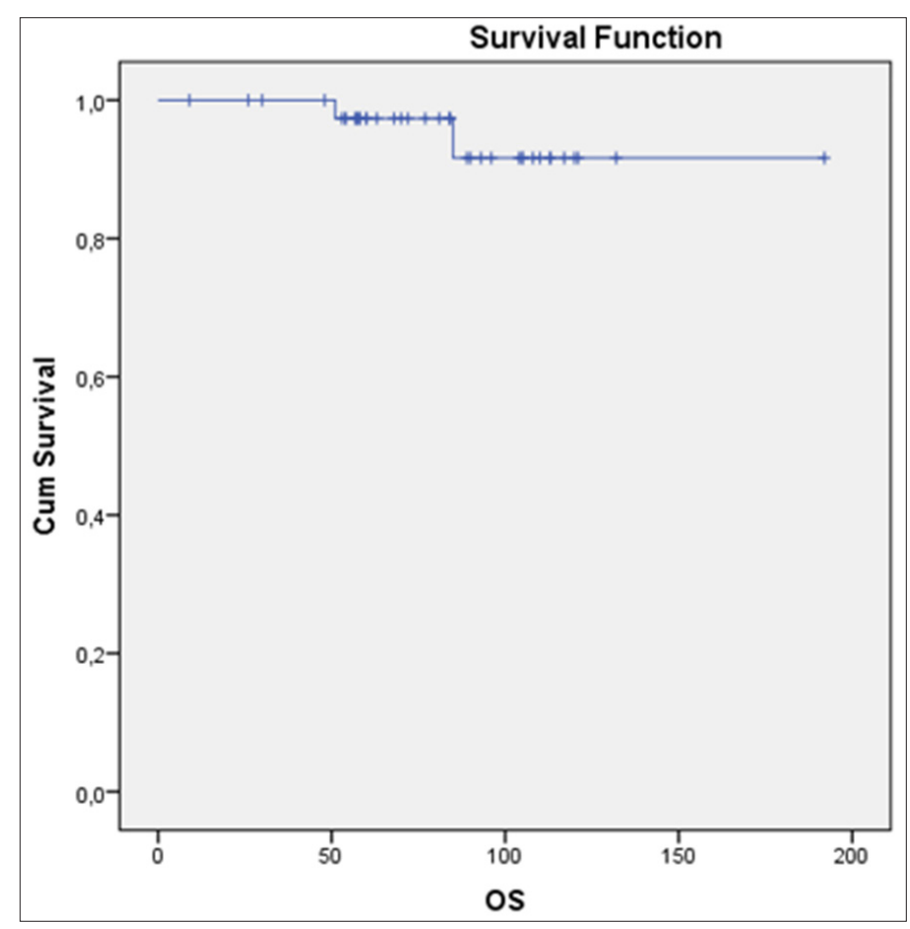

Figure 1C. Overall survival kaplan-meier curves of the surgically treated patients.

\section{DISCUSSION}

In this study, we evaluated endometrial cancer (EC) in women aged $\leq 40$ years of age according to prognostic factors that effected survival and successful outcome. Endometrial cancer is the most common gynecologic cancer in women

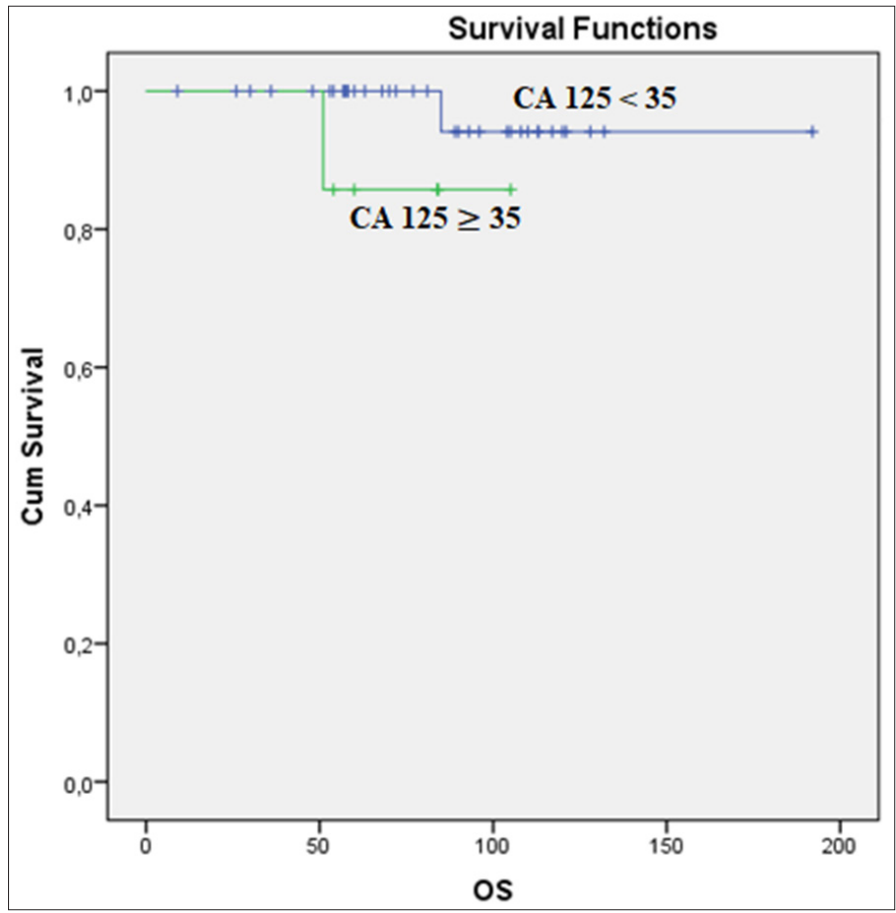

Figure 1B. Overall survival kaplan-meier curves of the patients according to the ca 125 level

most of whom are postmenopausal. The median age at

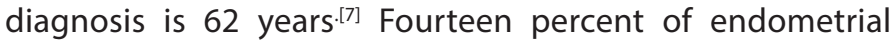
cancers are diagnosed in premenopausal women, and approximately $5 \%$ occur in women aged 40 years or younger. ${ }^{[8,9]}$ In the present study $1.4 \%(54 / 3878)$ of the endometrial cancer patients were 40 years old or younger. $1.4 \%$ ratio only reflects a single center in the Aegean region of Turkey. This ratio may be higher in our country. Chronic anovulation, insulin resistance, infertility, obesity, polycystic ovary syndrome (PCOS), exposure to high estrogen levels and inherited genetic mutations can be factors for the development of endometrial cancer in young women. In young patients, endometrial cancers with low grade and no evidence of myometrial invasion, tend to behave favorably than in older patients. ${ }^{[4,10]}$ However, Tran et al. demonstrated that endometrial cancers in women aged $\leq 45$ years of age had similar outcomes to that of older women. ${ }^{[11]}$

Well-differentiated and uterus confined disease has a $93 \%$ 5-year survival. ${ }^{[12]}$ In our study, the early-stage patient ratio was $85.8 \% .14 .3 \%$ of patients had advanced (stage 3 ) disease. When we identified stage 3 patients; 2 had adnexal micrometastasis, 1 had only 9 months follow-up period, 3 had lymph node metastasis without capsule invasion. Dissected lymph node numbers were enough in this study. Although $14.3 \%$ had advanced disease, these patients had a $91.6 \% 5$-year survival. This can be attributed to the favorable histopathologic features of the tumor, like micrometastasis, lymph node metastasis without extra-capsular extension, and also attributed to the well-tolerated full dose and on time adjuvant therapies. 
In literature, it was stated that patients with grade 1 disease have about $3 \%$ and $2 \%$ of pelvic and para-aortic dissemination, respectively. ${ }^{[13]}$ In the present study, patients with grade 1 disease who underwent staging surgery, had no lymph node metastasis. We found that lymph node metastasis was statistically associated with increasing tumor grade. Sun et al. revealed that higher-grade EC is associated with worse survival in young patients. ${ }^{[2]}$ In the present study grade was not associated with survival in cox regression analysis.

Increased serum CA 125 levels correlate with the disease stage and some histologic parameters. ${ }^{[14,15]}$ Lymph node metastasis is widely recognized as the main prognostic factor for endometrial cancer. ${ }^{[16]}$ Although in literature it was suggested that an age-dependent cut-off level for CA 125 , in our study we aimed to identify whether CA 125 levels $\geq 35 \mathrm{IU} / \mathrm{ml}$ was associated with poor prognostic factors. In this study we found that CA 125 levels were associated with lymph node metastasis with cut-off level of $35 \mathrm{U} / \mathrm{mL}$ (p:0.004). Goksedef et al also reported that, 5-year PFS and OS rates were significantly better in patients with serum CA 125 level $<35 \mathrm{U} / \mathrm{mL}$ than in those with a level $\geq 35 \mathrm{U} / \mathrm{mL} .{ }^{[17]}$

Chao et al. reported that elevated CA 125 levels ( $>35 \mathrm{U} / \mathrm{mL}$ ) were associated with worse clinicopathologic features such as deep myometrial invasion, advanced-stage and poor outcome. ${ }^{[14]}$ In our study increased CA 125 levels ( $\geq 35 \mathrm{U} /$ $\mathrm{mL}$ ) were also associated with deep myometrial invasion $(p=0.044)$ and patients who demonstrated CA 125 levels of $\geq 35$ had shorter OS and DFS compared with patients with CA 125 levels of $<35(97.2 \pm 7.1$ vs $1848 \pm 6.8$ months, $p=0.10$ and $97 \pm 7.4$ vs. $184.8 \pm 6.8$ months, $p=0,10$, respectively). However, this difference was not statistically significant.

In the present study, $78.6 \%$ of patients had LVSI. In one study it was stated that LVSI is a predictive factor for both nodal metastasis, and decreased survival. ${ }^{[18]}$ Besides, several studies revealed that stage, MI, grade, LVSI, lymph node metastasis, cervical stromal invasion were poor prognostic factors. ${ }^{[19-21]}$ However, in our study stage, tumor size, LVSI, CA 125 level, tumor grade, RT and recurrence had no impact on OVS and DFS in univariate cox regression analysis.

Several published studies report on the use of imaging studies for assessing MI. One study reported the best results with contrasted MRI. ${ }^{[22]}$ In our clinic, we used contrasted MRI for evaluating MI in 2 patients who had a desire for preserving fertility.

Endometrial cancer management in young women who desire future fertility has several challenges. The National Comprehensive Cancer Network and the European Society of Gynecological Oncology recommend progestin therapy for patients with $\mathrm{EC}$ who wish to conceive. ${ }^{[23]}$ In the present study two patients ( 37 and 38 years old, respectively) with endometrial cancer diagnosed with endometrial curettage received medical treatment with megestrol acetat (160 $\mathrm{mg} /$ day) and LNG-IUD, respectively. These two patients had grade 1 endometrioid adenocarcinoma, normal CA 125 level and normal BMI. Pelvic MRI did not show any MI, extrauterine spread or adnexial pathology. Detailed information was given and all possible results regarding medical treatment were explained to the patients. Informed consent was obtained. After 3 months of treatment, dilatation and curettage was performed. One of them had focal atypical endometrial hyperplasia within an endometrial polyp and regression within the rest of the endometrium, the other had complete regression. At every 6 months they were evaluated with endometrial biopsy. After 3 years, one patient underwent hysterectomy while the other was using medical treatment with medroxyprogesterone acetate intermittently during fertility treatment. Recent studies have reported that LNG-IUD plus oral progestin achieved better results than only LNG-IUD. ${ }^{[2,25]}$ Falcone et al. reported $93.3 \%$ pregnancy rate and $86.6 \%$ live birth rate among women who tried to conceive after conservative treatment. ${ }^{[26]}$ In the present study two of the conservative treated patients did not achieve pregnancy after the 36th month of the medical treatment.

Kim et al. stated that $46.4 \%$ of the samples obtained by using the endometrium sampling method were insufficient. ${ }^{[27]}$ In our study we performed D\&C for evaluating the two patients treated medically, after removing the LNG-IUD and cessation of oral progestin treatment. Ramirez et al. reported that the median time for a complete response was 12 weeks (range, 4-60 weeks). ${ }^{[28]}$ If the disease progresses, definitive surgical treatment should be applied. However, if the disease persists, progestin treatment can be continued for 9-12 months. ${ }^{[2,12]}$ Erkanli et al. reported progestin treatment duration, between 3 and 36 months in their study. ${ }^{[30]}$ The benefits of continuing the progestin treatment after complete regression is not clear. ${ }^{[29]}$ In the present study one patient had complete response after 3 months of treatment and was still using medroxyprogesterone acetate intermittently for menstrual dysfunction during fertility treatment.

For preservation of oocytes, Wright et al. stated that ovarian preservation was a reasonable option in some young women with endometrial cancer. ${ }^{[31]}$ In the present study a 35-year-old patient underwent only total abdominal hysterectomy operation and her ovaries were preserved. Patient's stage was IA, histologic type was endometrioid, and tumor size was $2 \mathrm{~cm}$. No recurrence was detected with a follow-up of 68 months.

In women under the age of 50 years when diagnosed with endometrial cancer and who have a family history of endometrial or colorectal cancer, genetic counseling should be provided. The genetic syndromes most commonly associated with endometrial cancer are nonpolyposis colorectal cancer, also known as Lynch Syndrome, and Cowden Syndrome. ${ }^{[32,33]}$ The main limitation of this study is its small sample size and retrospective design. 


\section{CONCLUSION}

Endometrial cancer is not common in patients younger than 40 years of age, and tends to behave favorably when compared to older women. The present study demonstrated that stage, tumor size, LVSI, CA 125, tumor grade, adjuvant $\mathrm{RT}$ and recurrence were not predictive factors for survival in women aged $\leq 40$ years of age. These patients had a favorable 5 -year survival rate with a $91.6 \%$ ratio. CA 125 level $\geq 35$ IU/ $\mathrm{ml}$ was statistically significantly associated with extrauterine disease. Although it is not possible to arrive at definitive conclusions based only on the 2 patients in our study, we believe that a comprehensive evaluation with physical examination, imaging and laboratory studies have important role in achieving the best survival results for these patients. All possible outcomes associated with medical treatment must be explained to these patients and informed consent must be obtained. Larger prospective series are needed to further evaluate women $\leq 40$ years of age and to assess young women who desire fertility individually.

\section{ETHICAL DECLARATIONS}

Ethics Committee Approval: The study was conducted in accordance with the Declaration of Helsinki, and the protocol was approved by the Ethics Committee of number 2020/ 1133 on 14.09.2020.

Informed Consent: Written consent was obtained from all patients who participated in the study and their relatives.

Referee Evaluation Process: Externally peer-reviewed.

Conflict of Interest Statement: The author(s) declared no potential conflicts of interest with respect to the research, authorship, and/or publication of this article.

Financial Disclosure: The authors declared that this study has received no financial support.

Author Contributions: All of the authors declare that they have all participated in the design, execution, and analysis of the paper, and that they have approved the final version.

Acknowledgement: We would like to thank to all editors and reviewers.

\section{REFERENCES}

1. Mazzon I, Corrado G, Masciullo V, Morricone D, Ferrandina G, Scambia G. Conservative surgical management of stage IA endometrial carcinoma for fertility preservation. Fertil Steril 2010;93:1286-89.

2. Sun C, Chen G, Yang Z, et al. Safety of ovarian preservation in young patients with early-stage endometrial cancer: a retrospective study and meta-analysis, Fertil. Steril. 2013;100(3):782-87.

3. Iram S, Musonda P, Ewies AA. Premenopausal bleeding: when should the endometrium be investigated? A retrospective non-comparative study of 3006 women. Eur J Obstet Gynecol Reprod Biol 2010;148:86-9.

4. Navarria I, Usel M, Rapiti E, et al. Young patients with endometrial cancer: how many could be eligible for fertility-sparing treatment? Gynecol. Oncol. 2009;114(3):448-51.

5. Farhi DC, Nosanchuk J, and Silverberg SG. Endometrial adenocarcinoma in women under 25 years of age. Obstet Gynecol.1986;68:741-45.
6. Chi DS, Barakat RR, Palayekar MJ, et al. The incidence of pelvic lymph node metastasis by FIGO staging for patients with adequately surgically staged endometrial adenocarcinoma of endometrioid histology Int J Gynecol Cancer. 2008;18:269-73.

7. National Cancer Institute Cancer stat facts: uterine cancer.[https://seer cancer.gov/statfacts/html/corp.html]

8. Lee NK, Cheung MK, Shin JY, et al. Prognostic factors for uterine cancer in reproductive-aged women. Obstet Gynecol. 2007;109(3):655-62.

9. Rodolakis A, Biliatis I, Morice P, et al. European Society of Gynecological Oncology Task Force for Fertility Preservation: clinical recommendations for fertility-sparing management in young endometrial cancer patients. Int J Gynecol Cancer. 2015; 25:1258-65.

10. Silverberg SG, Makowski EL, Roche WD. Endometrial carcinoma in women under 40 years of age: comparisonof cases in oral contraseptive users and non-users. Cancer 1977;39:592-98.

11. Tran BN, Connell PP, Waggoner S, Rotmensch J, Mundt AS. Characteristics and outcome of endometrial carcinoma patients age 45 years and younger. Am J Clin Oncol. 2000;23(59):476-80.

12. Kaku T, Yoshikawa $H$, Tsuda $H$, et al. Conservative therapy for adenocarcinoma and atypical endometrial hyperplasia of the endometrium in young women: central pathologic review and treatment outcome. Cancer Lett 2001;167:39-48.

13. Creasman WT, Morrow CP, Bundy BN, Homesley HD, Graham JE, Heller PB. Surgical pathologic spread patterns of endometrial cancer. A gynecologic oncology group study Cancer 1987;60(8):2035-41.

14. Chao A, Tung $\mathrm{YH}$, Lai $\mathrm{CH}$, et al. Potential of an age stratified CA125 cutt of value to improve the prognostic classification of patients with endometrial cancer. Gynecol Oncol 2013;129:500-04.

15. Yildiz A, Yetimalar H, Kasap B, et al. Preoperative serum CA 125 level in the prediction of the stage of disease in endometrial carcinoma, Eur. J. obstetrics, Gynecol. reproductive Biol. 2012;164(2):191-95.

16. Koskas M, Fournier M, Vanderstraeten A, et al. Evaluation of models to predict lymph node metastasis in endometrial cancer: a multicentre study. Eur J Cancer. 2016;61:52-60.

17. Goksedef PC, Gorgen H, Baran SY, Api M, Cetin A. Preoperative serum CA 125 level as a predictor for metastasis and survival in endometrioid endometrial cancer. J Obstet Gynaecol Can. 2011;33(8):844-50.

18. Guntupalli SR, Zighelboim I, Kizer NT, et al. Lymphovascular space invasion is an independent risk factor for nodal disease and poor outcomes in endometrioid endometrial cancer, Gynecol. Oncol. 2012;124(1):31-35.

19. Creutzberg CL, Van Putten WL, Koper PC, et al. Surgery and postoperative radiotherapy versus surgery alone for patients with stage-1 endometrial carcinoma: multicentre randomised trial. PORTEC Study Group. Post Operative Radiation Therapy in Endometrial Carcinoma, Lancet. 2000;355(9213):1404-11.

20. 20.Yamazawa K, Seki K, Matsui H, Kihara M, Sekiya S. Prognostic factors in young women with endometrial carcinoma: a report of 20 cases and review of literature. Int J Gynecol. Cancer. 2000;10(3):212-22.

21. Gungor T, Cetinkaya N, Ozdal B, Yalcin H, Erkaya S, Yakut HI. Endometrial. adenocarcinoma in young-aged women: a Turkish population study. Eur J Gynaecol Oncol 2015;36(6):667-71.

22. Zarbo G, Caruso G, Caruso S, Mangano U, Zarbo R. Endometrial Cancer: prospective evaluation of myometrial infiltration: magnetic resonance imaging versus tranvaginal sonography Eur J Gynaecol Onco.2000;21:9597.

23. National Comprehensive Cancer Network (US) Uterine neoplasms Plymouth Meeting, PA: National Comprehensive Cancer Network; 2018.

24. Pashov Al, Tskhay VB, lonouchene SV. The combined GnRH-agonist and intrauterine levonorgestrelreleasing system treatment of complicated atypical hyperplasia and endometrial cancer: a pilot study. Gynecol Endocrinol 2012;28:559-61.

25. 25.Brown AJ, Westin SN, Broaddus RR, Schmeler K. Progestin intrauterine device in an adolescent with grade 2 endometrial cancer. Obstet Gynecol 2012;119(2):423-26. 
26. Falcone F, Laurelli G, Losito S, Di Napoli M, Granata V, Greggi S. Fertility preserving treatment with hysteroscopic resection followed by progestin therapy in young women with early endometrial cancer. J Gynecol Oncol. 2017;28(1):2.

27. Kim DH, Seong SJ, Kim MK, et al. Dilatation and curettage is more accurate than endometrial aspiration biopsy in early-stage endometrial cancer patients treated with high dose oral progestin and levonorgestrel intrauterine system. J Gynecol Oncol. 2017;28(1):1.

28. Ramirez PT, Frumovitz M, Bodurka DC, Sun CC, Levenback C. Hormonal therapy for the management of grade 1 endometrial adenocarcinoma: A literature review. Gynecol. Oncol 2004; 95: 133-38.

29. Park JY, Kim DY, Kim JH, et al. Long-term oncologic outcomes after fertility-sparing management using oral progestin for young women with endometrial cancer. Eur JCancer 2013; 49(4): 868-74.

30. Erkanli S, Ayhan A. Fertility-sparing therapy in young women with endometrial cancer: 2010 update. Int J Gynecol Cancer 2010;20:1170-87.

31. 31. Wright JD, Jorge S, Tergas Al, et al. Utilization and Outcomes of Ovarian Conservation in Premenopausal Women With Endometrial Cancer. Obstet. Gynecol. 2016;127 (1):101-8.

32. Lynch HT, Snyder CL, Shaw TG, Heinen CD, Hitchins MP. Milestones of Lynch syndrome: 1895-2015. Nat Rev Cancer. 2015;15:181-94.

33. Wong A, Ngeow J. Hereditary Syndromes Manifesting as Endometrial Carcinoma: How Can Pathological Features Aid Risk Assessment? Biomed Res Int. 2015;2015:219012. 